\title{
SURGICAL MANAGEMENT OF TRAUMATIC NON-INFECTIVE TENOSYNOVITIS OF THE WRIST EXTENSORS
}

\author{
J. G. P. Williams, Farnham Royal, Buckinghamshire, England
}

\begin{abstract}
Traumatic tenosynovitis of the wrist extensors is a common and disabling condition associated with overuse. It has been found to be associated with hypertrophy of the bellies of abductor pollicis longus and extensor pollicis brevis where they overlie the radial extensor tendons in the forearm, compressing these tendons and their enveloping paratenons against the deep structures beneath. Simple surgical decompression of the sheath of these overlying muscles has been found to give quick relief of symptoms and to allow a more rapid return to strenuous work than the conservative treatments usually employed.
\end{abstract}

Traumatic tenosynovitis (peritendinitis crepitans) is a common overuse injury typified by "an acute inflammatory reaction around the tendon as a result of repetitive movements which impose a strain upon it" (Aston 1974). The condition has been described as affecting the radial extensors of the wrist (Kelly and Jacobson 1964), the extensors of the toes over the dorsum of the foot, the hamstrings at their insertion behind the knee and the calcaneal tendon (Williams 1976). It is associated with pain, swelling and crepitus on movement, and may give rise to considerable functional disability.

Differential diagnosis of peritendinitis is primarily from tendovaginitis, to which it is related and with which it may be confused if the normal anatomical relationships are forgotten. Some cases may represent the first manifestations of generalised rheumatic disease.

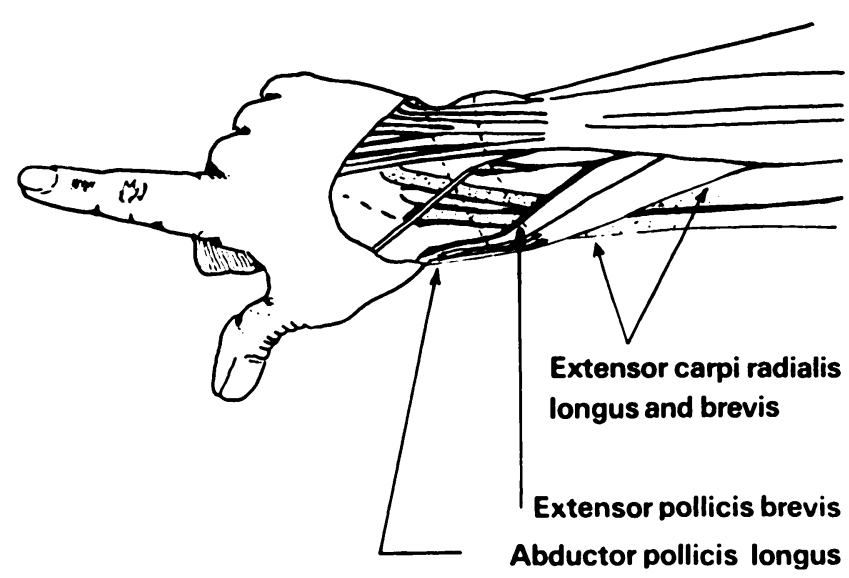

FIG. 1
Conventional treatment involves a degree of rest (Wiles and Sweetnam 1965), frequently enforced by immobilisation in plaster-of-Paris, together with antiinflammatory drugs, both systemically and, as in the case of steroid preparations, by local injection; the use of heparin (Kvist 1958) and enzyme preparations such as hyaluronidase has been recommended (Bellmann, Zacharias and Böhland 1970), as has physiotherapy (Lanfear and Clarke 1972).

Although such conservative measures may be effective, they inevitably involve a more or less prolonged period of abstinence from the provoking cause. This may be acceptable to the majority of patients but in some cases it is not, and a more quickly effective treatment must be found.

Tenosynovitis of the radial extensors of the wrist is particularly common and disabling in oarsmen and

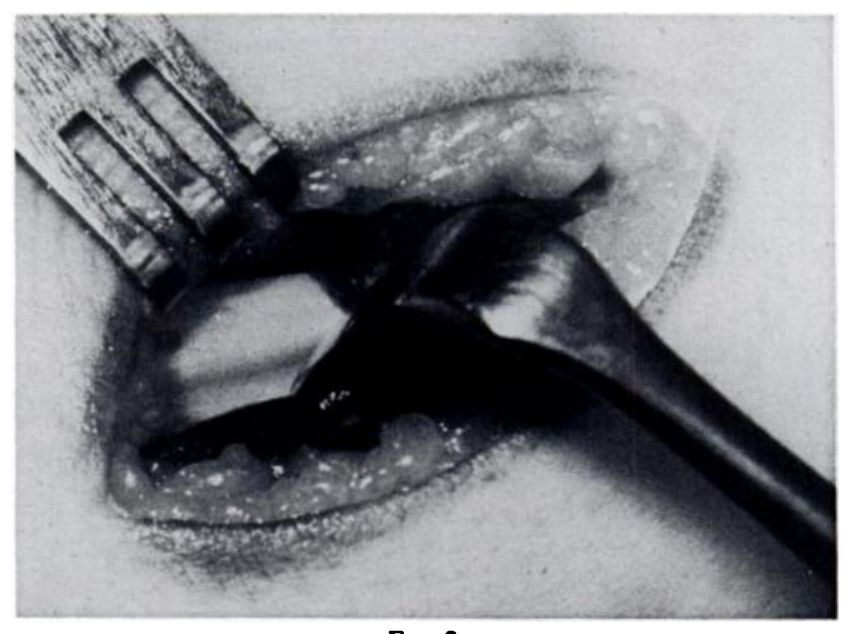

Fig. 2

Figure 1-Diagram to show extensor aspect of forearm with abductor pollicis longus and extensor pollicis brevis overlying the radial extensors of the wrist proximal to the extensor retinaculum. Figure 2-Muscle bellies retracted at operation to display underlying tendons.

J. G. P. Williams, M.A., M.B., B.Chir., F.R.C.S.Ed., D.Phys.Med., Medical Director, Farnham Park Rehabilitation Centre, Farnham Royal, Buckinghamshire SL2 3LR, England. 
TABLE 1

Detalls of Patients with Results of Surgery

\begin{tabular}{|c|c|c|c|c|c|c|c|c|c|}
\hline $\begin{array}{c}\text { Case } \\
\text { number }\end{array}$ & $\underset{\text { (years) }}{\text { Age }}$ & Sex & Side & $\begin{array}{c}\text { Provoking } \\
\text { activity }\end{array}$ & $\begin{array}{l}\text { Duration of } \\
\text { symptoms }\end{array}$ & \multicolumn{2}{|c|}{$\begin{array}{l}\text { Date of } \\
\text { operation }\end{array}$} & $\begin{array}{l}\text { Post-operative } \\
\text { disability }\end{array}$ & Outcome \\
\hline 1 & 22 & $\mathbf{M}$ & $\mathbf{R}$ & Rowing & 9 weeks & January & 1972 & $\begin{array}{l}\text { Returned to rowing } \\
\text { within } 1 \text { week }\end{array}$ & Competed Olympic Games 1972 \\
\hline 2 & 24 & $\mathbf{M}$ & $\mathbf{R}$ & Rowing & 18 months & March & 1972 & $\begin{array}{l}\text { Full training within } \\
1 \text { week }\end{array}$ & \\
\hline 3 & 22 & $\mathbf{M}$ & $\mathbf{R}$ & Rowing & 3 weeks & March & 1974 & Training 5 days later & $\begin{array}{l}\text { Silver Medal 8o, World Champion- } \\
\text { ships } 1974\end{array}$ \\
\hline 4 & 24 & $\mathbf{M}$ & $\mathbf{L}$ & Rowing & 12 months & January & 1975 & Training next day & \\
\hline 5 & 26 & $\mathbf{M}$ & $\mathbf{R}$ & Rowing & 2 weeks & February & 1975 & Training next day & $\begin{array}{l}\text { Competed World Championships } \\
1975 \text {; Silver Medal 8o, Olympic } \\
\text { Games } 1976\end{array}$ \\
\hline 6 & 21 & $\mathbf{M}$ & $\mathbf{R}$ & Rowing & 3 weeks & February & 1975 & Training next day & \\
\hline 7 & 39 & $\mathbf{F}$ & $\mathbf{R}$ & Nursing & 2 months & July & 1975 & $\begin{array}{l}\text { Normal work } 4 \text { days } \\
\text { later }\end{array}$ & \\
\hline 8 & 22 & $\mathbf{F}$ & $\mathbf{L}$ & Canoeing & 3 weeks & August & 1975 & Training next day & $\begin{array}{l}\text { Won National K4 Championships } \\
16 \text { days later }\end{array}$ \\
\hline 9 & 27 & $\mathbf{M}$ & L & Rowing & 3 weeks & January & 1976 & Training next day & $\begin{array}{l}\text { Won selection for } 4 s \text { National } \\
\text { Squad } 8 \text { days later for Olympic } \\
\text { Games } 1976\end{array}$ \\
\hline 10 & 26 & $\mathbf{F}$ & $\mathbf{L}$ & Housework & 3 months & January & 1976 & $\begin{array}{l}\text { Symptom-free within } \\
5 \text { days }\end{array}$ & \\
\hline 11 & 23 & F & $\mathbf{R}$ & Typing & 3 months & April & 1976 & $\begin{array}{l}\text { Symptom-free within } \\
5 \text { days }\end{array}$ & \\
\hline
\end{tabular}

canoeists and the form of surgical treatment here described was initially devised for the management of an Olympic oarsman. Experience in his case led to a similar technique being used on other patients, including oarsmen, canoeists and individuals whose work and domestic requirements called for restoration of full function of the hand and wrist as a matter of urgency (Table I).

\section{RATIONALE}

Tenosynovitis of the radial extensors of the wrist is frequently accompanied by swelling over the radial aspect of the dorsum of the forearm. Surgical exploration in the first case showed that there was marked hypertrophy of the long abductor and short extensor muscles of the thumb where they crossed the radial extensor tendons (Figs. 1 and 2), the paratenons of which were found to be grossly inflamed and adherent. Excision of this pathological tissue, with decompression of the sheath of the overlying muscles, eliminated the patient's symptoms within a day of operation and he was able to resume considerable activity while the sutures were still in place. It was therefore postulated that the condition was primarily due to hypertrophy combined with acute overuse oedema in the long abductor and short extensor muscles of the thumb, causing compression of the underlying tendons and their surrounding tissues. Thus it seemed possible that simple decompres- sion of the muscles might relieve pressure on the paratenon and other structures around the radial extensor tendons, and lead to an early resolution of symptoms.

\section{TECHNIQUE OF OPERATION}

Decompression of the abductor longus and extensor brevis is carried out without a tourniquet under local anaesthetic through an incision three to four centimetres long aligned over the muscle bellies (Fig. 3). The subcutaneous tissue is opened in the axis of the muscle and,

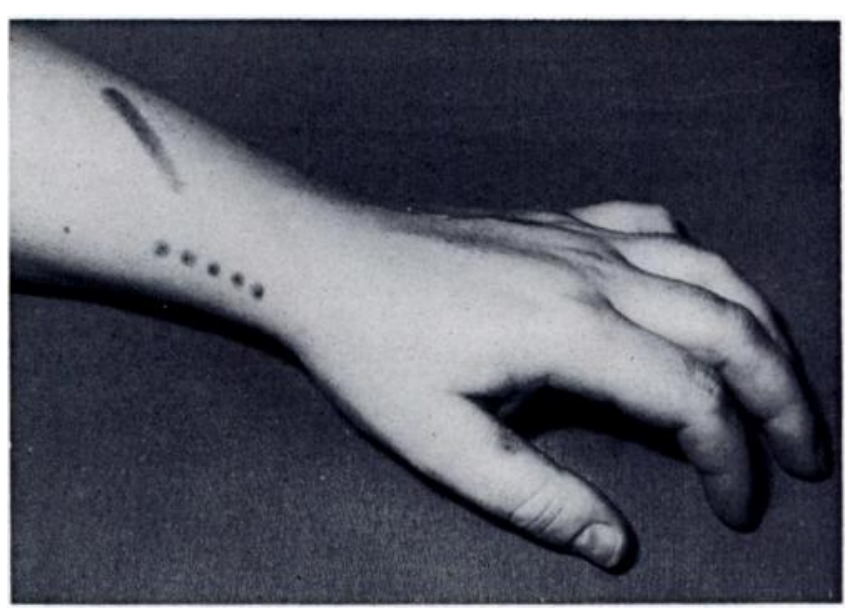

Fig. 3

Site of incision for decompression of abductor longus and extensor brevis muscle bellies ( - ): contrast with site for incision to decompress tendons for de Quervain's disease $(\cdots \cdots)$. 


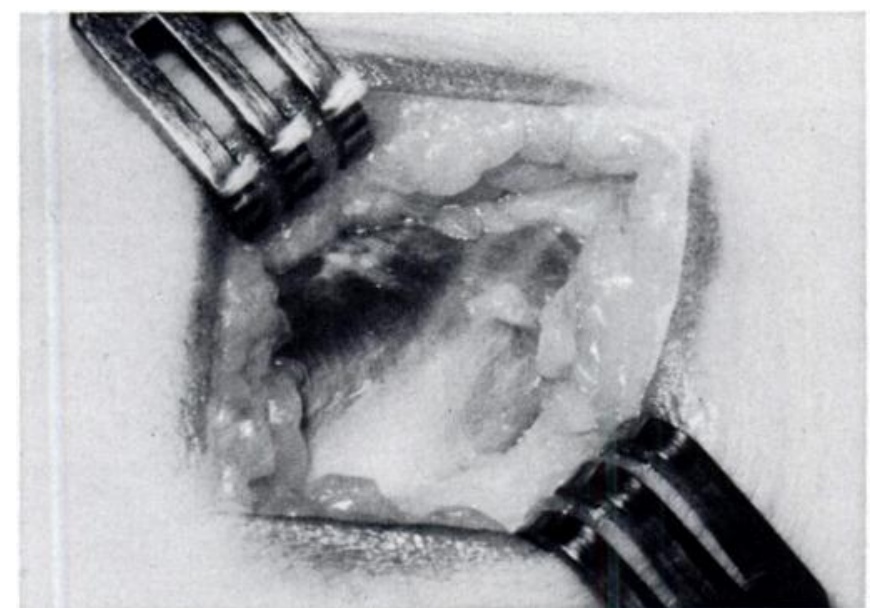

Fig. 4

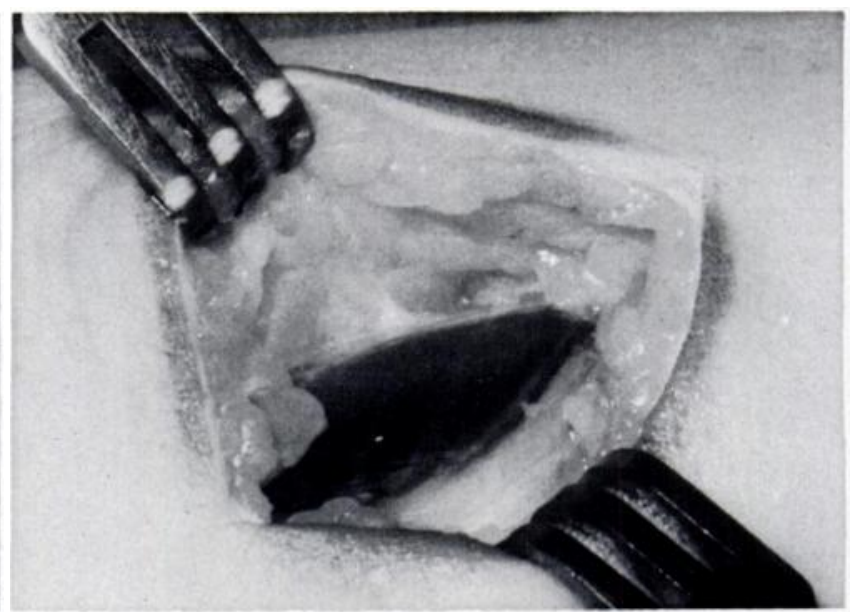

Fig. 5

Decompression of abductor longus and extensor brevis: muscle bellies displayed before (Fig. 4) and after (Fig. 5) longitudinal division of the sheath.

after the muscles have been displayed (Fig. 4), the sheath is divided longitudinally from the musculotendinous junction to the point at which the muscle bellies disappear deep into the forearm. As decompression is carried out the muscles bulge up through the opening (Fig. 5): they may be attached to the overlying fascial sheath by soft filmy oedematous adhesions. The subcutaneous tissue and skin are then closed in layers. A sling is not provided after this procedure, but a light crepe bandage over a Melolin dressing is worn for two days. The dressing is then removed and replaced by plastic spray and a Tubigrip support. Sutures are removed on the tenth day after operation.

\section{RESULTS}

All patients in this series regained useful painless function in the arm within twenty-four hours of operation (Table I). The sportsmen returned to light sporting activity on the day after the operation and all were in full training before the sutures were removed. Full normal activity had also been resumed by the other patients before the removal of their sutures.

Both the short-term and long-term results have been satisfactory. There has been no recurrence, nor any other after-effect in any patient, the longest followup being now four years.

\section{DISCUSSION}

Non-infective (traumatic) tenosynovitis (peritendinitis crepitans) of the radial extensor tendons of the wrist may be largely due to compression of the tendons beneath the swollen hypertrophied bellies of the abductor longus and extensor brevis muscles of the thumb. An operation for the decompression of these muscles and thus of the underlying tendons has given uniformly satisfactory results in all cases so far treated. It is suggested that decompression of the abductor longus and extensor brevis muscles in the forearm offers a satisfactory and effective means of treating acute or chronic tenosynovitis of the radial tendons of the wrist for patients in whom early resumption of full normal activity is important.

\section{REFERENCES}

Aston, J. N. (1974) A Short Textbook of Orthopaedics and Traumatology. Second "revised" edition. London: English Universities Press Ltd. Bellmann, H., Zacharias, J., and Böhland, W. (1970) Anwendung von Hyaluronidase bei Paratenonitis crepitans und Tendinosen (Epicondylitis humeri und Periarthritis humero-scapularis). Zeitschrift für ärztliche Fortbildung, 64, 385-390.

Kelly, A. P., Jun., and Jacobson, H. S. (1964) Hand disability due to tenosynovitis. Industrial Medicine and Surgery, 33, 570-574.

Kvist, H. (1958) Heparin vid achillessen-skada hos idrottsmän. Nordisk Medicin, 60, 1289-1290.

Lanfear, R. T., and Clarke, W. B. (1972) The treatment of tenosynovitis in industry. Physiotherapy, 58, 128-129.

Wiles, P., and Sweetnam, R. (1965) Essentials of Orthopaedics. Fourth edition. London: J. and A. Churchill.

Williams, J. G. P. (1976) Injuries of the lower limbs. In Sports Medicine. Second edition. Edited by J. G. P. Williams and P. N. Sperryn. London: Edward Amold. 